\title{
HUBUNGAN PENGGUNAAN GADGET TERHADAP RISIKO GANGGUAN PEMUSATAN PERHATIAN DAN HIPERAKTIVITAS ANAK USIA PRASEKOLAH DI PAUD CEMPAKA DESA BATU MEKAR LINGSAR
}

\author{
Indah Wasliah $^{1}$, Eka Adithia Pratiwi ${ }^{2}$, Ni Luh Pebri Pradnyantayani ${ }^{3}$ \\ 1) Prodi Ners Stikes Yarsi Mataram \\ ${ }^{2,3)}$ Prodi S.1 Keperawatan Stikes Yarsi Mataram \\ indahwasliah80@gmail.com
}

\begin{abstract}
ABSTRAK
Prevalensi gangguan pemusatan perhatian dan hiperaktivitas menurut Biro Sensus Amerika Serikat memperkirakan 7,2\% anak berusia 5-19 tahun diseluruh dunia memiliki gangguan pemusatan perhatian dan hiperaktivitas (CHDAA The National Resource on $A D H D, 2015)$. Penyebab gangguan pemusatan perhatian dan hiperaktivitas adalah faktor lingkungan. Salah satu contoh faktor lingkungan adalah penggunaan gadget. Indonesia diprediksikan masuk kategori empat besar populasi pengguna gadget terbesar di dunia. Penggunaan gadget yang secara berlebihan pada anak akan meningkatkan kecanduan gadget. Kecanduan gadget merupakan salah satu penyebab dari GPPH. Penelitian ini bertujuan untuk mengetahui hubungan penggunaan gadget terhadap risiko gangguan pemusatan perhatian dan hiperaktivitas pada anak usia prasekolah (3-6 tahun) di PAUD Cempaka Desa Batu Mekar Kecamatan Lingsar. Jenis penelitian ini yaitu kolerasi dengan desain penelitian yang digunakan pada penelitian ini adalah cross sectional dan menggunakan lembar Abbreviated Conners Rating Scale sebagai instrumen. Pengambilan sampel dalam penelitian ini menggunakan tekhnik total sampling yaitu teknik pengambilan sampel dengan jumlah sampel 52 orang. Hasil penelitian ini menunjukkan bahwa anak yang paling banyak menggunakan gadget yaitu pada kategori sedang sebanyak 24 orang $(46,2 \%)$ dan 3 orang $(5,8 \%)$ mengalami risiko gangguan pemusatan perhatian dan hiperaktivitas. Hasil uji Chi Square didapatkan $p$ value menunjukkan bahwa $(\mathrm{p}=0,038<\alpha=0,05)$ maka dapat disimpulkan bahwa ada hubungan antara penggunaan gadget dengan gangguan pemusatan perhatian dan hiperaktivitas pada anak usia prasekolah (3-6 tahun) di PAUD Cempaka. Berdasarkan hasil penelitian, disarankan bagi orang tua untuk lebih selektif dalam memberikan mainan berupa penggunaan gadget pada anak.
\end{abstract}

Kata kunci : Gadget, GPPH, AnakUsia 3-6 tahun

\section{THE CORRELATION OF USING GADGETSTOW ARDDISTURBANCES ATTENTION CAUTION AND HYOERTACTIVITY RISK ONPRE SCHOOL CHILDREN IN PAUD CEMPAKA BATU MEKAR VILLAGE LINGSAR}

\begin{abstract}
The prevalence of disturbances attention and hyperactivity disorders according to the USA Census Bureau estimated that 7,2\% of children ages 5-19 years worldwide have disturbances attention and hyperactivity (CHDAA The National Resource on ADHD, 2015). The cause of disturbances attention and hyperactivity disorders was
\end{abstract}


environmental factors. One example of environmental factors is the use of gadgets. Indonesia is predicted to be in the top four categories of the largest gadget user in the world. Excessive use of gadgets in children will increase gadget addiction. Gadgets addiction is one of the causes of GPPH. The aimed of this research is to determine the correlation between the use of gadgets and the disturbances attention and hyperactivity disorder in preschool children (3- 6 years old) in PAUD Cempaka, Batu Mekar Village, Lingsar. The type of this research was correlation, research design used in this research was cross sectional and it was used Abbreviated Conners Rating Scale sheet as an instrument. Sampling technique used in this research was total sampling; the samples used in this research there were 52 people. The results of this research indicate that the most children who using gadgets with moderate category there were 24 people $(46,2 \%)$ and 3 people $(5,8 \%)$ obtained of disturbances attention and hyperactivity disorder. Chi Square test results obtained p-value shows that $(p=0,038<\alpha=0,05)$, it can be concluded that there is a correlation between the use of gadgets with disturbances attention and hyperactivity disorders on preschool children (3-6 years) in PAUD Cempaka. Based on research results, it is recommended for parents to be more selective in providing toys especially the use of gadget to children.

\section{Keywords : Gagdet, GPPH, Children 3-6 years old}

\section{PENDAHULUAN}

Gangguan pemusatan perhatian dan hiperaktivitas (GPPH) atau yang lebih dikenal dengan attention deficit hyperactivity disorde (ADHD) merupakan suatu gangguan perilaku yang banyak terjadi pada anakanak.Gangguan pemusatan perhatian dan hiperaktivitas (GPPH)didefinisikan sebagai suatu gangguan psikiatrik yang cukup banyak ditemukan dengan gejala utama inatensi (kurangnya perhatian), hiperaktivitas, dan impulsivitas (bertindak tanpa berpikir) yang tidak konsisten dengan tingkat perkembangan anak, remaja, atau orang dewasa (Mirnawati dan Amka, 2019).

Prevalensi GPPH menurut Biro Sensus Amerika Serikat memperkirakan 7,2\% anak berusia 5-19 tahun di seluruh dunia pada tahun 2013 memiliki GPPH (CHDAA The National Resource on $A D H D, 2015)$. Tahun 2016 di Amerika Serikat menyatakan bahwa pada anak usia 2-17 tahun terdapat sekitar 6,1 juta anak yang menderita GPPH. Di Indonesia belum ada data pasti mengenai jumlah GPPH.Menurut penelitian Dhea
Novita, dkk (2019) di Bandar Lampung menunjukkan 8,2\% anak suspect GPPH. Penyebab GPPH bersifat multifaktorial mulai dari faktor genetik, kerusakan otak dan faktor lingkungan.(Mirnawati dan Amka, 2019). Salah satu faktor lingkungan adalah penggunaan gadget contohnya penggunaan smartphonedan tablet. Byun Yoon-hwan menyimpulkan dalam penelitiannya bahwa penggunaan smartphone meningkatkan risiko munculnya gejala GPPH (Byun et al., 2013).

Gadget merupakan barang canggih yang diciptakan dengan berbagai aplikasi yang dapat menyajikan berbagai media berita, jejaring sosial, hobi bahkan hiburan (Widiawati dkk, 2014).Gadget tidak hanya digunakan oleh orang dewasa dan remaja.Gadget sekarang juga banyak digunakan oleh anak prasekolah (3-6 tahun) yang seharusnya belum waktunya untuk menggunakan gadget. Pada usia3-6 tahun perkembangan anak sangat sensitif sehingga sering disebut the golden age. 
Pada masa ini seluruh aspek perkembangan kecerdasaan, yaitu kecerdasaan intelektual, emosi dan spiritual mengalami perkembangan yang luar biasa sehingga yang akan mempengaruhi dan menentukan perkembangan selanjutnya.

Menurut survey eMarketer (2015) didapatkan data pengguna gadget meningkat secara signifikan. Indonesia diprediksikan masuk empat besar populasi pengguna gadget terbesar di dunia. Sedangkan untuk di wilayah Asia Tenggara, Indonesia merupakan pengguna gadget tertinggi mencapai 92 juta pengguna pada tahun 2019. Menurut Asosiasi Penyelenggara Jasa Internet (APJIII) (2014), Nusa Tenggara Barat merupakan pengguna internet tertinggi di wilayah Nusa Tenggara, Papua dan Maluku yaitu mencapai 2.4 juta pengguna, pada tahun 2018 di NTB mencapai $68,2 \%$ pengguna.

Meningkatnya jumlah penggunaan gadgetakan meningkatkan angka kecanduan gadget. Menurut penelitian Zaini dan Soenarto (2019) di Yogyakarta menyatakan bahwa anak usi 4-6 tahun menikmati dalam memainkan smartphone dan tablet mereka dan $26 \%$ anak sudah mengalami kecanduan gadget. Kecanduan gadget pada anakanak disebabkan karena fitur menarik dan kecanggihan yang terkandung di dalamnya. Selain itu, rasa penasaran yang tinggi membuat anak-anak terus memainkan gadget dalam waktu yang lama. Kecanduan gadget akan menimbulkan banyak kerugian antara lain penurunan kosentrasi, menghambat perkembangan motorik, penurunan dalam berosialisasi, mengalami gangguan kesehatan mata dan menghambat perkembangan kognitif anak (Handrianto, 2013). Kecanduan gadget juga akan meningkatkan prevalensi risiko gangguan pemusatan perhatian dan hiperaktivitas karena kecanduan gadget mempengaruhi pelepasan hormon dopamin yang berlebihan sehingga menyebabkan penurunan kematangan Pre Frontal Cortex (PFC). Hal ini dapat menjadi salah satu penyebab GPPH (Paturel, 2014).

Berdasarkan studi pendahuluan yang dilakukan peneliti di TK/PAUD Cempaka terhadap 5 orang anak, 4 diantaranya menggunakan gadget dengan rata-rata durasi 5-30 menit perhari dengan intensitas 1-2 kali perhari dan 1 orang anak menggunakan gadget dengan durasi 40-60 menit perhari dengan intensitas >3kali sehari dan menurtu salah satu dari guru di Paud tersebut terdapat salah satu murid yang mengalami suspect gangguan pemusatan perhatian dan hiperaktivitas yang meliputi; sulit konsentrasi, sering menginggalkan tempat duduk di dalam kelas saat gurunya meminta untuk tetap duduk, sering berlarian atau naik-naik secara berlebihan dalam situasi sedang berdoa bersama dan melakukan aktivitas lain secara berlebihan di luar batas normal anak lainnya.

\section{METODE PENELITIAN}

Desain penelitian yang digunakan adalah penelitian korelasional atau kolerasi yaitu mengidentifikasi adanya hubungan penggunaan gadget terhadap risiko gangguan pemusatan perhatian dan hiperaktivitas pada anak prasekolah (3-6 tahun) di Paud Cempaka Desa Batu Mekar Kecamatan Lingsar. Dengan menggunakan pendekatan penelitian cross sectional yaitu penelitian yang dilakukan pada satu waktu dan satu kali untuk mencari hubungan variabel independen dan dependen (Wallen, 2008).

Populasi dalam penelitan ini adalah anak usia 3-6 tahun sebanyak 52 orang, di Paud Cempaka Desa Batu Mekar Kecamatan Lingsar Kabupaten Lombok Barat. Instrumen penelitian 
yang digunakan adalah lembar observasi dan lembar Abbreviated Conners Rating Scale (ACRS). Lembar observasi bertujuan untuk mengisi data dari orang tua atau pengasuh mengenai intensitas dan durasi penggunaan gadget pada anak, sedangkan lembar kuesioner ACRS terdiri dari 10 pertanyaan yang ditanyakan kepada orang tua atau pengasuh anak. Masing-masing pertanyaan dinilai menurut tingkat aktivitas anak, yaitu skor nol (tidak sama sekali), satu (kadang-kadang), dua (sering), tiga (hampir selalu). Sehingga skor total minimal nol dan maksimal 30. Anak yang dinyatakan sebagai suspect GPPH apabila skor total lebih dari atau sama dengan 13.

Sampling atau tehnik pengambilan sampel merupakan sebuah proses penyeleksian jumlah dari populasi untuk dapat mewakili populasi. Tehnik pengambilan sampel adalah berbagai cara yang ditempuh untuk pengambilan sampel agar mendapatkan sampel yang benar-benar sesuai dengan seluruh subjek penelitian tersebut (Nursalam, 2013). Tehnik pengambilan sampel dalam penelitian ini adalah dengan total sampling. Total sampling adalah tehnik pengambilan sampel dimana jumlah sampel sama dengan populasi (Sugiyono, 2011). Alasan mengambil total sampling karena menurut Sugiyono (2011) jumlah populasi yang kurang dari 100 , seluruh populasi dijadikan sampel penelitian.

Analisis data menggunakan analisa univariat dan bivariat, yang mana dalam analisa data tersebut menggunakan uji Chi Square dengan bantuan komputer dengan Software SPSS For Windows Versi 19.

\section{HASIL PENELITIAN}

\section{Karakteristik Responden Di PAUD Cempaka

\begin{tabular}{crrr}
\hline No & Karakteristik & Frek & $(\%)$ \\
\hline 1 & Usia Responden & &
\end{tabular}

\begin{tabular}{llcc} 
& 4 tahun & 2 & 3,8 \\
& 5 tahun & 9 & 17,3 \\
& 6 tahun & 41 & 78,8 \\
& Jumlah & 52 & 100 \\
& Usia Penggunaan Gadget & & \\
& & & \\
& 3 tahun & 2 & 3,8 \\
& 4 tahun & 11 & 21,2 \\
& 5 tahun & 22 & 42,3 \\
& 6 tahun & 17 & 32,7 \\
& Jumlah & 52 & 100 \\
& Jenis Gadget & & \\
& Notebook & 2 & 3,8 \\
Ipad & 9 & 17,3 \\
& Handphone & 41 & 78,8 \\
& Jumlah & 52 & 100 \\
\hline
\end{tabular}

Berdasarkan Tabel di atas, diketahui bahwa usia responden pada usia 6 tahun memiliki jumlah yang paling banyak yaitu 41 responden $(78,8 \%)$ dan jumlah responden paling sedikit berusia 4 tahun yaitu sebanyak 2 responden $(3,8 \%)$. Jumlah responden yang mulai menggunakangadget pada usia 5 tahun memiliki jumlah paling banyak yaitu 22 responden (42,3\%). Sedangkan jenis gadget yang paling banyak digunakan yaitu handphone sebanyak 41 (78,8\%).

\section{Distribusi Frekuensi Penggunaan Gadget Di PAUD Cempaka

\begin{tabular}{ccc}
\hline $\begin{array}{c}\text { Penggunaan } \\
\text { Gadget }\end{array}$ & Jumlah & Presentase $(\%)$ \\
\hline Rendah & 11 & 21,2 \\
Sedang & 24 & 46,2 \\
Tinggi & 17 & 32,7 \\
\hline Jumlah & 52 & 100 \\
\hline
\end{tabular}

Berdasarkan tabel diatas, diketahui bahwa penggunaan gadget tertinggi yaitu pada kategori sedang yaitu sebanyak 24 responden (46,2\%), penggunaan gadget paling sedikit yaitu pada kategori rendah sebanyak 11 responden $(21,2 \%)$ dan kategori tinggi sebanyak 17 responden $(32,7 \%)$.

3. Distribusi Frekuensi Responden Berdasarkan Risiko Gangguan Pemusatan Perhatian dan Hiperaktivitas Usia 3-6 tahun Di PAUD Cempaka

\begin{tabular}{cc}
\hline $\begin{array}{c}\text { Gangguan Pemusatan } \\
\text { Perhatian dan }\end{array}$ & Jumlah \\
$\begin{array}{c}\text { Presentase } \\
\text { Hiperaktivitas Usia 3- }\end{array}$ \\
6 tahun
\end{tabular}




\begin{tabular}{ccc}
\hline Normal & 49 & 94,2 \\
Berisiko & 3 & 5,8 \\
\hline Jumlah & 52 & 100 \\
\hline
\end{tabular}

Berdasarkan tabel diatas, diketahui bahwa responden yang tidak berisiko gangguan pemusatan perhatian dan hiperaktivitas lebih banyak yaitu sebanyak 49 responden $(94,2 \%)$ sedangkan untuk responden yang berisiko yaitu sebanyak 3 responden $(5,8 \%)$.

4. Analisis hubungan penggunan gadget terhadap risiko gangguan pemusatan perhatian dan hiperaktivitas pada anak usia 3-6 tahun Di PAUD Cempaka

\begin{tabular}{|c|c|c|c|c|c|c|c|}
\hline \multirow{3}{*}{$\begin{array}{c}\text { Pengguna } \\
\text { an } \\
\text { Gadget }\end{array}$} & & $\begin{array}{l}\text { gguan } \\
\text { Perhat } \\
\text { Hipera }\end{array}$ & $\begin{array}{l}\text { mi } \\
\text { di } \\
\text { vit }\end{array}$ & $\tan$ & & \multirow{3}{*}{$\begin{array}{l}\text { Total } \\
\text { P Valu }\end{array}$} & \\
\hline & \multicolumn{2}{|c|}{ Normal } & \multicolumn{2}{|c|}{ Berisiko } & & & \\
\hline & $\mathrm{F}$ & $\%$ & $\mathrm{~F}$ & $\%$ & & & \\
\hline Rendah & 11 & 100 & 0 & 0,0 & 11 & 100 & \\
\hline Sedang & 24 & 100 & 0 & 0,0 & 24 & 100 & 0,038 \\
\hline Tinggi & 14 & 82,4 & 3 & 17,6 & 17 & 100 & \\
\hline Jumlah & 49 & 94,2 & 3 & 5,8 & 52 & 100 & \\
\hline
\end{tabular}

Berdasarkan tabel diatas, dapat diketahui terdapat 3 responden $(17,6 \%)$ yang menggunakan gadget dengan kategori tinggi dan mengalami risiko gangguan pemusatan perhatian dan hiperaktivitas. Kemudian terdapat 11 responden $(100 \%)$ dengan kategori rendah dan 24 responden (100\%) dengan kategori sedang tidak mengalami risiko gangguan pemusatan perhatian dan hiperaktivitas.

Hasil uji Chi Square diperoleh nilai $\mathrm{p}$ value $(\mathrm{P}=0,038<\alpha=0,05)$ maka dapat disimpulkan bahwa Ha diterima dan Ho ditolak atau ada hubungan antara penggunaan gadget terhadap risiko gangguan pemusatan perhatian dan hiperaktivitas pada anak usia 3-6 tahun di PAUD Cempaka Desa Batu Mekar Kecamatan Lingsar.

\section{PEMBAHASAN}

\section{Penggunaan Gadget Pada Anak}

Berdasarkan hasil penelitian yang dilakukan di Paud Cempaka Desa Batu Mekar, sebagian besar anak usia 3-6 tahun memiliki kebiasaan menggunakan gadget dalam kategori sedang yaitu dengan durasi 40-60 menit dan intesitas 2-3 kali/hari yaitu sebanyak 24 responden $(46,2 \%)$, penggunaan gadget paling sedikit yaitu pada kategori rendah sebanyak 11 responden $(21,2 \%)$ dan kategori tinggi sebanyak 17 responden $(32,7 \%)$.

Gadget merupakan tekhnologi terbaru yang memiliki kemampuan lebih baik dan fitur terbaru dan memiliki tujuan dan fungsi yang praktis dan lebih berguna (Friedman, 2010). Beberapagadget yang sekarang banyak digunakan oleh anak-anak yaitu smartphone,handphone, laptop, tablet $p c$, dan video game (Iswidharmanjaya, 2014). Hasil dari penelitian ini menunjukkan anak-anak di PAUD Cemapaka banyak menggunakan gadget dengan jenis handphone, yaitu sebanyak 41 (48,8\%). Perkembangan gadget di era yang semakin berkembang ini memiliki dampak positif dan dampak negatif bagi penggunanya. Menurut Hendrianto (2013) salah satu dampak negatif dari gadget yaitu dapat menyebabkan kecanduan gadget. Menurut penelitian yang dilakukan oleh Rideout (2013) didapatkan hasil anak usia 2-4 tahun menggunakan gadget dengan durasi 1 jam 58 menit dan anak usia 5-8 tahun menggunakan gadget dengan durasi 2 jam 21 menit setiap harinya. Hal ini bertentangan dengan pendapat Starburger (2011) yang menyatakan durasi penggunaan gadget pada anak tidak boleh lebih dari $>1$ jam setiap harinya. Setianingsih, dkk (2018) juga 
mengatakan bahwa anak yang menghabiskan waktu lebih dari 60 menit untuk bermain gadget memiliki risiko tinggi mengalami gangguan pemusatan perhatian dan hiperaktivitas.

Menurut Sari dan Mitsalia (2016) penggunaan gadget dikategorikan menjadi 3 kategori, yaitu dikategorikan tinggi jika menggunakan gadget dengan durasi penggunaan 75-120 menit dengan intensitas >3kali/hari, penggunaan gadget dikategorikan sedang dengan durasi 40-60 menit dengan intensitas maksimal 2kali/hari dan dikategorikan rendah dengan durasi 5-30 menit dengan intensitas 1-2 kali/hari.

Hasil penelitian ini menunjukkan sebagian besar anak di PAUD Cempaka berusia 6 tahun dan rata-rata mulai menggunakan gadget pada usia 5 tahun. Usia ini disebut golden age, pada usia ini anak mengalami perkembangan yang luar biasa sehingga mempengaruhi perkembangan selanjutnya. Pada masa ini rasa ingin tahu anak pada objek sangat tinggi, terutama pada objek yang menampilkan fitur-fitur menarik seperti gadget dan juga ketertarikan akan kecanggihan dari gadget. Menurut Fadilah (2015) fiturfitur yang menarik pada gadget dan kecanggihan gadget merupakan faktor yang mempengaruhi penggunaan gadget. Menurut Byun et al (2013) anak yang menggunakan gadget pertamanya pada usia $<6$ tahun mempunyai risiko lebih tinggi mengalami gangguan psikolog dan cenderung menunjukkan gejala inatensi, sehingga penggunaan gadget pada anak harus diperhatikan.

Pada bagian hasil penelitian ini dapat dilihat bahwa terdapat selisih jumlah yang cukup banyak antara anak yang menggunakan gadget dengan durasi dan intensitas rendah dengan anak yang menggunakan durasi dan intesitas sedang dan tinggi. Hal ini dikarenakan anak-anak selalu beranggapan bahwa fitur-fitur yang ada pada gadget dan kecanggihan gadget merupakan sesuatu hal yang sangat menarik untuk dilihat dan dimainkan.

\section{Gangguan Pemusatan Perhatian dan Hiperaktivitas Pada Anak Usia 3-6 Tahun}

Hasil penelitian menunjukkan sebagian besar responden pada penelitian ini berada dalam rentang normal yaitu sebanyak 49 responden (94,2\%). Hal ini mengindikasikan bahwa anak-anak di PAUD Cempaka tidak mengalami risiko gangguan pemusatan perhatian dan hiperaktivitas seperti hiperaktif, tidak mampu memusatkan perhatian, ketidakstabilan emosional dan kesulitandalam menyelesaikan tugas.Hasil penelitian ini juga menunjukkan sebanyak 3 responden $(5,8 \%)$ di PAUD Cempaka mengalami risiko gangguan pemusatan perhatian dan hiperaktivitas.

Gangguan pemusatan perhatian dan hiperaktivitas adalah suatu gangguan psikiatrik yang cukup banyak ditemukan dengan gejala utama kurangnya perhatian, bertindak tanpa berfikir yang tidak konsisten dengan tingkat perkembangan anak, remaja, atau orang dewasa (Mirnawati dan Amka, 2019).Gangguan ini merupakan gangguan neurobiologis dengan tingkat inatensi yang berkembang tidak sesuai dan perkembangan neurologis yang mempengaruhi kemampuan seseorang untuk mengatur dan mencegah perilaku serta mempertahankan perhatian pada area otak yang 
mengatur implus (Baihaqi dan Sugiarmin, 2008).

Faktor penyebab dari gangguan pemusatan perhatian dan hiperaktivitas pada anak di PAUD Cempaka yaitu penggunaan gadget yang berlebihan yang terlalu dini. Menurut Millichap (2008) penggunaan gadget yang berlebihan ini termasuk dalam faktor lingkungan. Sebagian besar anak di PAUD Cempaka mulai menggunakan gadget pada usia 5 tahun. Menurut Byun et al (2013) anak-anak yang menggunakan gadget pada usia $<6$ tahun mempunyai risiko lebih tinggi mengalami gangguan psikolog dan cenderung mengalami gejala inatensi.

Menurut hasil penelitian yang dilakukan oleh Setianingsih, dkk (2018) mengatakan bahwa anak yang mengahabiskan waktu lebih dari 60 menit unuk bermain gadget memiliki risiko gangguan pemusatan perhatian dan hiperaktivitas. Penggunaan gagdet selain memiliki dampak positif juga memiliki dampak negatif, seperti penurunan kosentrasi, menghambat perkembangan motorik anak, penurunan dalam bersosialisai dan mengalami kecanduan gadget. Kecanduan gadget dapat mempengaruhi perkembangan otak anak karena produksi hormon dopamine yang berlebihan mengganggu kematangan fungsi prefrontal korteks sehingga dapat menimbulkan gangguan pemusatan perhatian dan hiperaktivitas, seperti gagal dalam menyelesaikan kegiatan, kurang perhatian atau kurang konsentrasi, melakukan aktivitas secara berlebihan.

\section{Hubungan Penggunaan Gadget Terhadap Risiko Gangguan Pemusatan Perhatian dan Hiperaktivitas Pada Anak Usia Prasekolah (3-6 tahun)}

Dari hasil analisis hubungan penggunaan gadget dengan gangguan pemusatan perhatian dan hiperaktivitas pada anak usia prasekolah (3-6 tahun) didapatkan bahwa anak yang mengalami risikogangguan pemusatan perhatian dan hiperaktivitas sebanyak 3 responden $(17,6 \%)$ dengan kategori penggunaan gadget tinggi, yaitu dengan durasi penggunaan gadget 75120 menit dan intensitas penggunaan >3kali/hari. Hasil uji Chi Square menunjukkan bahwa penggunaan gadget terhadap risiko gangguan pemusatan perhatian dan hiperaktivitas pada anak usia prasekolah di PAUD Cempaka ( $\mathrm{P}=$ $0,038<\alpha=0,05)$ maka dapat disimpulkan bahwa ada hubungan antara penggunaan gadget terhadap risiko gangguan pemusatan perhatian dan hiperaktivitas pada anak usia prasekolah (3-6 tahun).

Dari hasil penelitian yang dilakukan oleh peneliti dapat dilihat bahwa 3 responden anak yang mengalami risikogangguan pemusatan perhatian dan hiperaktivitas disebabkan karena penggunaan durasi dan intensitas gadget yang berlebihan yaitu pada rentan ketegori penggunaan gadget tinggi, selain itu anak juga terlalu dini untuk dikenalkan dengan gadget. Dari hasil penelitian didapatkan bahwa sebagian besar anak mulai menggunakan gadget pertama mereka pada usia 5 tahun.

Menurut Ferliana (2016), anak dibawah usia 5 tahun dapat menggunakan gadget akan tetapi harus diperhatikan durasi dan intensitas penggunaannya, seperti boleh menggunakan gadget tetapi dengan durasi $<1$ jam dengan intensita 1-2 kali/hari. Anak yang kecanduangadgetrelatif menjadi anak yang pendiam, acuh atau sulit untuk 
diajak berbicara secara langsung, kurang konsentrasi atau gagal dalam menyelesaikan tugasnya.

Menurut Dhea Novita, dkk (2019) tidak semua anak yang bermain gadget mengalami risiko gangguan pemusatan perhatian dan hiperaktivitas. Penelitan mereka menyebutkan bahwa penggunaangadget terhadap gangguan pemusatan perhatian dan hiperaktivitas pada anak usia sekolah di SD Al Kautsar lebih banyak anak yang tidak mengalami risiko gangguan pemusatan perhatian dan hiperaktivitas dibandingkan dengan anak yang mengalami risiko gangguan pemusatan perhatian dan hiperaktivitas yaitu sebanyak 91,8\%. Hal ini dikarenakan anak yang mengalami kecanduan gadget lebih sedikit dibandingkan anak yang mengalami kecanduan gadget.

Tidak dapat dipungkiri bahwa di era modern ini banyak yang sudah menggunakan gadget tidak hanya pada orang dewasa tetapi anak-anak yang masih dalam masa golden age sudah bisa mengoperasikan gadget. Kecanggihan dan fitur-fitur yang menarik pada gadget membuat anakanak menjadi tertarik dan kecanduan menggunakan gadget. Kecanduan gadget pada anak dapat meningkatkan risiko terjadinya gangguan pemusatan perhatian dan hiperaktivitas. Menurut Paturel (2014) kecanduan gadget akan mempengaruhi pelepasan hormon dopamin yang berlebihan sehingga menyebabkan penurunan kematangan Pre Frontal Cortex (PFC) yang menjadi salah satu penyebab gangguan pemusatan perhatian dan hiperaktivitas.

\section{REFERENSI}

ADHD Institude. (2017). Enviromental Risk Factors. (diunduh 1 Februari 2020). Tersedia dari:http://adhdinstitude.com/burden-ofadhd/aetiology/enviromental-riskfactors

American Psyciatric Association. (2013). Diagnostic and Statistic Manual of Mental Disorder, Fifth edition: DSM 5. Washington: American Psychiatric Association

Angliadi L, Sengkey L, Gessal J \& Mogi T. (2006). Ilmu Kedokteran Fisik dan Rehabilitasi. Fakultas Kedokteran Universitas Sam Ratulangi: Manado

Armendarez JJ. (2015). Video Game Use Among Children and Adolescents With Attention Deficit Hyperactivity Disorder. Kingston: University of Rhode Island.

APJII. (2018). Responden Survei Penetrasi Pengguna Internet. (diunduh 30 November 2019). Tersedia dari http://apjii.or.id

Baihaqi dan M. Sugiarmin. (2008). Memahami dan Membantu Anak ADHD. Bandung: PT Refika Aditama

Byun YH, Ha M, Kwon HJ, Hong YC, Leen JH, Sakong J, et al. (2013). Mobile phone Use, Blood Lead Levels, and Attetion Deficit Hyperactivity Symptoms in ChildernI : A Longitudinal Study. PLOS ONE. Vol 8, No 3 (1-10)

CHDAA The National Resource on ADHD. (2015). (diunduh 1 Februari 2020). Tersedia dalam http://www.chadd.org/understandi ng-adhd/about-adhd/data- andstatistic/general-prevalence.aspx

Chu S \& Reynolds F. (2007). Occupational Therapy for Children with Attention Deficit Hyperactivity Disorder (ADHD), Part 1: a delineation model of 
practice. Br J Occup Ther. 70(9): 372-383

Dahlan, M.S. (2014). Langkah-langkah Membuat Proposal Penelitian Bidang Kedokteran dan Kesehatan. Jakarta: Sagung Seto

Derry Iswidharmajaya, B.A. (2014). Bila $\mathrm{Si}$ Kecil Bermain Gadget. Bisakimia: Yogyakarta

Dhea Novita, Dyah Wulan Sumekar Rengganis Wardani, Evi Kurniawaty. (2019). Hubungan Penggunaan Gadget (Smartphone) Dengan Suspek Gangguan Pemusatan Perhatian dan Hiperaktivitas Di SD Al Kautsar Bandar Lampung. Vol.8, No.1 (108-114)

Dr. H. Yusuf, Syamsu. (2011). Psikologi Perkembangan Anak dan Remaja.PT.Remaja Rosdakarya: Bandung

Elcom. (2011). Google Android. Andi Publisher: Jakarta

E-Marketer. (2015). Proyeksi Penggunaan Smartphone di Asia Tenggara.

(diunduh 30 November 2019). Tersedia dari Dkatadata.co.id

Fadilah, R. (2015). Perilaku Konsumtif Mahasiswa UGM dalam Penggunaan Gadget. Yogyakarta: UGM

Hardianto. (2013). Dampak Positif dan Dampak Negatif Penggunaan Gadget Bagi Anak. Bumi Askara: Jakarta

Jaka, Irawan \& Leni Ramayati. (2013). Pengaruh Kegunaan Gadget Terhadap Kemampuan Bersosialisasi Pada Remaja. Jurnal An-Nafs. Vol 8, No 2 (28-39).

Kementrian Kesehatan RI. (2016). Pedoman Pelaksanaan Stimulasi, Deteksi dan Intervensi Dini Tumbuh Kembang Anak Ditingkat Pelayanan Kesehatan Dasar. Kementerian Kesehatan RI: Jakarta
Lalusu R, Kaunang TM \& Kandou LJ. (2014). Hubungan Gangguan Pemusatan Perhatian dan Hiperaktivitas dengan Prestasi Belajar pada Anak SD Kelas 1 di Kecamatan Wenang Kota Manado. Jurnal e-CliniC (eCI). Vol 2, No 1 (1- 5)

Marchak, A. (2017). Attention Deficit Hiperactivity Disorder (ADHD): Pathogenesis and clinical findings. The Calgary Guide to Understanding Disease. (diunduh 1 Februari 2020). Tersedia dari : calgaryguide.ucalgary.ca/attentiondeficit-hyperaktivity-disorderadhd- pathogenesis-and-clinicalfindings/

Millchap, JG. (2008). Etiologic Classification of AttentionDeficit/Hyperactivity Disorder (ADHD). Pediatrics. Vol 121, No 2 (358-365)

Minarwati dan Amka. (2019).

Pendidikan Anak ADHD.

Yogyakarta: CV Budi Utama

National Institute of Mental Health. (2016). AttentionDeficit/Hyperactivity Disorder (ADHD): THE BASICS. Maryland: National Insitute of Mental Health. hlm 1-8

Notoatmodjo, S. (2012). Promosi Kesehatan \& Ilmu Perilaku. In Jakarta: Rineka Cipta.

Nursalam. (2013). Konsep Penerepan Metode Penelitian Ilmu Keperawatan.

Salemba Medika: Jakarta

Paturel. (2014). Game Theory : How Do Video Games Affect The Developing Brains Of Childern And Teens. LWW Journal. Vol 10, No 3 (32-36)

Purwanti A, Mexitalia, Wistiani \& Mellyana O. (2017). Symposium dan Workshop Early Detection on Neurodevelopmental Disorders. Badan Penerbit UNDIP: Semarang 
Rideout V. (2013). Zero to eight: electronic media in the lives of infants, toddlers and preschoolers. Common Sense Media Research Study

Sari, P dan Mitsalia A.A. (2016). Pengaruh Penggunaan Gadget Terhadap Personal Sosial Anak Usia Prasekolah. Jurnal Profesi. Vol 13, No 2 (72-77)

Setianingsih, Amila Wahyuni Ardani, Firiana Noor Khayati. (2018). Dampak Penggunaan Gadget Pada Anak Usia Prasekolah Dapat Meningkatkan Resiko Gangguan Pemusatan Perhatian dan Hiperaktivitas. Vol.XVI, No.2 (191-205)

Sudiharto.(2007). Konsep Perkembangan Gadget. EGC: Jakarta

Sugiyono. (2017). Pendekatan Kuantitatif, Kualitatif, Kombinasi, R\&D dan Penelitian Evaluasi. In Metodelogi Penelitian. Bandung: Alfabeta

Sugiyono. (2011).Metode Penelitian, Kuantitatif, Kualitatif dan R\&D. Bandung: Alfabeta

Swon K, Ho V, Tazkarji B \& Auten B. (2013). Management of ADHD in Preschool-Aged Children. University of Florida Helath Science Center Libraries: Florida

Wallen. (2008). Jenis-jenis Penelitian. EGC: Jakarta

Widiawati, I, Sugiman, H \& Edy. (2014). Pengaruh Penggunaan Gadget Terhadap Daya Kembang Anak. Vol. 6 (1-6) 